\title{
Reportagem \\ Pierre Zémor fala sobre comunicação pública na ENAP
}

"A noção de comunicação pública que Pierre Zémor nos passou foi o solo para o desenvolvimento de uma comunicação com o cidadão, para a construção e reforço do Estado democrático brasileiro. A consciência de uma comunicação cidadã foi o presente que ele nos deu no momento em que a dualidade Estado e empresa privada passou a ser permeada por uma sociedade civil organizada, que começava a surgir e a se formar politicamente." Assim a pesquisadora em comunicação pública Elizabeth Brandão resume a importância do pensamento do presidente da associação francesa Communication Publique, Pierre Zémor, que esteve na Escola Nacional de Administração Pública no dia 24 de abril para conduzir dois seminários.

A parceria entre a Secretaria de Comunicação Social da Presidência da República e a ENAP, com apoio da Embaixada da França, possibilitou a servidores públicos, jornalistas, assessores de comunicação do Executivo e do Legislativo, alunos e docentes o encontro com um dos maiores pensadores da comunicação pública.

Inicialmente, Zémor falou a dirigentes do governo sobre o papel da comunicação pública como estratégia. "Uma boa comunicação pública aumenta a legitimidade da instituição", disse, destacando que o objetivo é construir uma relação perene de confiança com o cidadão. E justificou: "As empresas podem mudar de cliente; os órgãos públicos, não.”

Já no seminário "Comunicação Pública: a experiência francesa”, que teve a participação das professoras Elizabeth Brandão e Heloiza Matos, Pierre Zémor mostrou a dificuldade de a comunicação pública se estabelecer na França em função da cultura institucional histórica de centralização e de informação contida - até secreta - da ação pública, naquele país. "Pelo que ouvi sobre comunicação pública, sobre o jornalismo público no Brasil, acredito que vocês tenham mais facilidade para promover essa comunicação, de modo mais natural", comentou.

\section{Como funciona}

O especialista francês, que também é conselheiro de Estado honorário, contou que há 25 ou 30 anos, quando a comunicação pública foi assim definida, houve intensos debates sobre os conceitos de comunicação do Estado, comunicação social, comunicação política e o da inédita comunicação pública.

Alguns queriam que jornalistas e publicitários fossem os responsáveis pela nova 
modalidade de comunicação; outros, que esta se limitasse à imprensa, à publicidade ou ao marketing. Zémor explica que para a democracia isso seria insuficiente. Era preciso ultrapassar o know-how da comunicação voltada a interesses econômicos, para o mercado concorrencial, para momentos de conquista de poder, como ocorre em período de eleições.

Chegou-se, então, à definição de comunicação pública: é o compartilhar e a troca de informações de utilidade pública, cuja responsabilidade cabe a uma instituição pública ou a um organismo que tem missão de interesse coletivo.

Para informar, compartilhar, trocar é preciso um emissor - que, neste caso, são as instituições públicas - e um receptor no serviço público, o cidadão. "O emissor deve saber qual o seu papel e limitá-lo para não se sentir obrigado a atender e responder a todas as perguntas, ainda que não seja competente para isso. A primeira condição para se comunicar bem com o receptor é ter lucidez em relação a si próprio", explica Pierre Zémor.

A segunda é levar em consideração o interlocutor, representado não somente pelo cidadão, mas por grupos da sociedade, associações profissionais, sindicatos. Zémor diz: "É preciso que a palavra pública seja capaz de se dirigir individualmente ou que tenha uma ressonância individual em mensagens destinadas à grande massa". Só assim, segundo ele, será possível distinguir a informação pública daquela concebida por publicitários ou jornalistas. "A grande diferença é o receptor ativo, ou seja, o cidadão capaz de influenciar as mensagens que recebe do emissor. Essa é a condição para que haja uma relação sem a qual ninguém consegue se entender, sem a qual é um diálogo de surdos", acrescenta.

\section{Cidadão}

A comunicação é a relação com o cidadão, afirma o especialista francês. "O cidadão é um eleitor, um contribuinte, um consumidor de serviços públicos. Então, como em uma democracia podemos mobilizar esse receptor?”, indaga e, prontamente, responde que o desafio é conhecer as preocupações de todos e saber que há conflitos em relação aos interesses da comunidade. "É preciso transporte, melhor qualidade de vida, menos deslocamento no trânsito, menos consumo. São problemas dessa natureza que precisam ser solucionados e, para isso, a comunicação é fundamental", diz.

Para Zémor, o comunicador público não precisa ser uma pessoa da área de comunicação. Ele explica que, tão logo surgiu a comunicação pública, a primeira ideia foi resolver os problemas superficiais, entre os quais, a relação com a mídia. Imaginava-se que um jornalista ou publicitário fosse o ideal. Logo em seguida, notou-se que os melhores comunicadores são pessoas vindas da própria instituição pública. "Isso porque falar de uma instituição pública não é tão simples quanto vender um produto. Há toda uma cultura de saberes tácitos e explícitos assimilada por pessoas que trabalham na instituição, conhecem os diversos processos de trabalho e podem atuar bem na área da comunicação pública, contando com outros profissionais para realizar vídeos, criar frases de impacto, terceirizar outros saberes", complementa.

Ao citar exemplos de como se fazer a comunicação pública, o professor mencionou associações que protestam sobre o funcionamento ruim dos serviços públicos. E lembrou que, nesses casos, há duas atitudes possíveis: "ou escutamos o que 
dizem, olhamos, vemos como levar em conta as suas observações e tentamos fazer com que o serviço evolua e sua comunicação também, ou ficamos indiferentes ao protesto e o risco é ter o divórcio entre a comunicação na sociedade e a comunicação das instituições públicas. Eu acho muito prejudicial quando há um corte. Pode ser um corte de pouco tempo, em poucos serviços, mas se esse corte for duradouro e se generalizar, podemos ter um aprisionamento dos poderes públicos", disse.

Outro paralelo feito com a comunicação política esclareceu melhor o funcionamento da comunicação pública. Pierre Zémor demonstrou que, na prática, a comunicação pública, cotidiana, institucional, aquela do dia a dia, apreende o essencial dos serviços de comunicação, ou seja, de $80 \%$ a $85 \%$. Os $15 \%$ ou $20 \%$ restantes, geralmente, não são atribuídos aos serviços de comunicação. São de gabinetes de ministros, de prefeitos, do governador. É uma comunicação com conteúdo mais político, já que se trata de implementar projetos de reformas, de mudanças. "Nessas situações, a melhor receita é comunicar-se o mais cedo possível com a população e ao longo de todo o processo de decisão", afirma.

$\mathrm{Na}$ França, Zémor presidiu a comissão nacional do debate público. Explicou, em sua palestra, que quando há um grande projeto a ser realizado no país, como os de infraestrutura, é preciso "montar um debate público, uma forma de associar o cidadão à decisão". Durante o debate, são feitas sugestões de adaptações e avaliadas as questões ambientais, entre outras. $\mathrm{O}$ mestre de obras e os líderes políticos são os que decidem, mas os cidadãos têm chance de opinar e suas ideias são normalmente aproveitadas.

\section{Comunicação direcionada}

Ao comparar a comunicação pública com a de massa, Pierre Zémor falou sobre a televisão. Embora seja um meio de comunicação de amplo alcance, ele acredita que não constitui a melhor forma de levar informação ao cidadão. Segundo explicou, $65 \%$ do que os telespectadores assistem ficam gravados como impressões, como imagens. "E é nesse ponto que percebemos

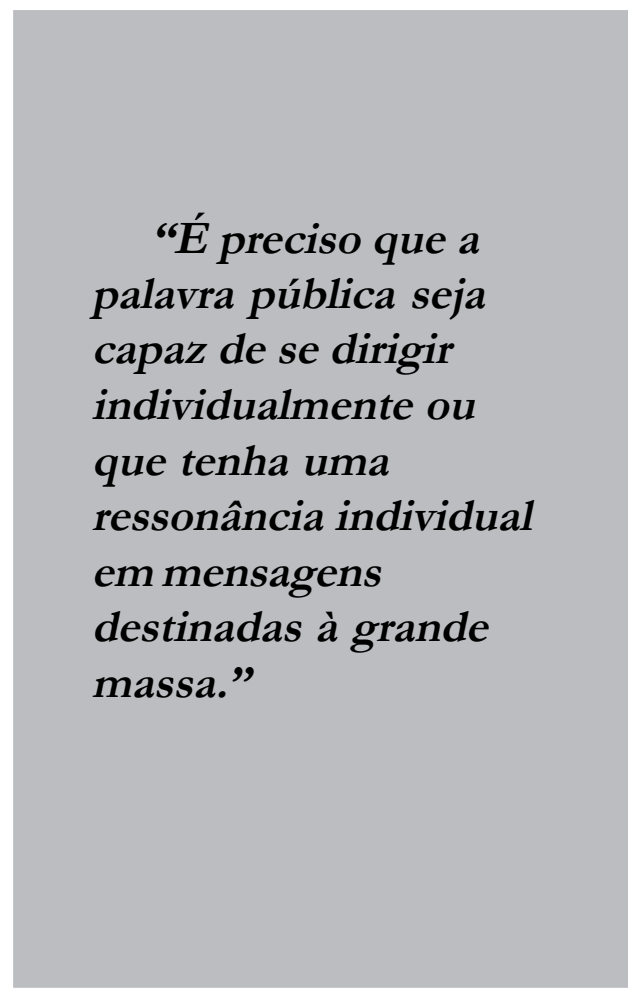

como a comunicação televisiva é efêmera. Mais fácil lembrar-se da gravata usada por um político que aparece no telejornal do que da mensagem por ele transmitida", diz.

A explicação para isso é a mobilização psicológica do telespectador diante do aparelho de TV, decorrente de uma relação instantânea estabelecida com o veículo. De acordo com pesquisas citadas por Zémor, o público que está convencido sobre 
alguma medida ou proposta mostra-se fortalecido em suas intenções, mesmo diante de um discurso político; o cético pode mudar de posição, mas depois de 48 horas volta a ser indiferente ao tema. "Para que a mensagem perdure, é preciso que o cidadão a ouça ativamente. O receptor deve ter a certeza de que pode influenciar a informação recebida", explica.

Pierre Zémor comentou, no encerramento da palestra, que o Brasil parecia ter um menor nível de dúvida, em relação à Europa e aos Estados Unidos, sobre a capacidade de sair da crise pela qual o mundo passa. E concluiu: "Não acredito que seja um otimismo unicamente devido ao samba, mas, sim, uma mistura de lucidez modesta e de grande capacidade de trabalho. Portanto, fiquei muito impressionado com aquilo que descobrimos nesse setor - já sabemos que o Brasil é credor do FMI. Para um país emergente, ele está em primeiro lugar na fila."

\section{Considerações}

Após a explanação de Pierre Zémor, as professoras Elizabeth Brandão e Heloiza Matos foram convidadas a comentar os temas abordados. Para a pesquisadora em Comunicação Pública Elizabeth Brandão, o pensamento de Zémor inspirou muitos jovens profissionais, na década de 1990 - época em que o livro La Communication Publique começou a ser disseminado nas universidades do Brasil -, especialmente por conta do período histórico vivido no país, de reconstrução da democracia e nascimento de uma nova sociedade civil.

Elizabeth comentou ainda que esse conceito ampliado de comunicação teve eco junto aos jovens estudantes e profissionais e, hoje, todos têm a honra de ser servidor público. "Há dez anos, dificilmente eu encontrava um servidor público brasileiro com orgulho de sua função. Normalmente ele era jornalista, administrador, economista. Nos últimos dez anos, o grande marco na área pública no Brasil foi recuperar o orgulho de ser servidor público", disse.

Já a professora e jornalista Heloiza Matos definiu como "inegável" a contribuição de Pierre Zémor no campo da comunicação pública. Segundo ela, uma das principais inovações do pensamento de Zémor foi a de mostrar que a comunicação pública não pode se restringir "às mensagens institucionais do governo aos que não têm voz". 